\title{
A SHORT REVIEW ON MICROEMULSION AND ITS APPLICATION IN EXTRACTION OF VEGETABLE OIL
}

\author{
Ashish D. Gadhave, Jyotsna T. Waghmare* \\ Department of Oils, Oleochemicals and Surfactant Technology, Institute of Chemical Technology, Nathalal Parekh \\ Road, Matunga East, Mumbai-400019. Maharashtra, India
}

\begin{abstract}
Conventional oil extraction method involves various volatile organic solvents (VOCs) that are considered as toxic and probable carcinogenic solvents. Though the risk to human health and environmental contamination exist while using these organic solvents in various processes, they are primarily being used on the back of their easy availability. Additionally, due the absence of any pretreatment, they are considered to be easy to handle. In order to reduce the exposure of these hazardous solvents, researchers are focusing on finding a substitute for the same. This review paper introduces the microemulsion technology as an alternate means of extraction of oils over conventional techniques. Microemulsion provides very efficient approach in oil extraction from oilseed on the back of its subcellular structure, ultralow interfacial tension, high thermal stability and high solubilization. The quality of oils obtained from microemulsion technology is very much comparable or even superior to that of organic solvent extraction method. This article would be helpful in developing more effective microemulsion formulations for extraction of oils.
\end{abstract}

Keywords: Microemulsion; Oil Extraction, Surfactant, Co-surfactant, Linkers. -***

\section{INTRODUCTION}

The global production of oilseeds during 2013-14 was tremendously higher at 504.3 million tons compared with 8.5 million tons in 1964-65 (World Agriculture Supply and Demand Estimates, 2014). With such volume expansion, oil extraction process has emerged as a significant activity in the industry.

In the conventional method, oil extraction is done physically by heating oilseeds with water and then separating the oil phase. In this process, salts are also added to coagulate proteins bound to fat molecules. Further, hand pressing (either cold or hot depending upon food matrix and chemical stability of oil to be extracted) is also practiced at medium level processing plants. Chemical method is preferred for large-scale production if oil content is less than 20\% (Snape \& Nakajima, 1996). In chemical method, an organic solvent (mostly hexane) is used to extract oil from milled seeds. These include peanut (Arachis hypogaea), soybean, sunflower, corn (Zea mays) and palm kernel (Mattil \& Norris, 1964). Solvent is then recovered after separating the oil by evaporation.

While high extraction temperature, in physical methods, destroys proteins and natural vitamin $\mathrm{E}$ content, lower temperature during cold pressing (in $50^{\circ}-70^{\circ} \mathrm{C}$ range) reduces yield (though with the limited damage) leading to increased cost of product. As defined by the US Environmental Protection Agency, particulate matter and volatile organic compounds are the principal emissions from vegetable oil processing. The industrial operations such as transfer, handling and processing of raw seeds involve generation of particulate matter (PM). The oil extraction process causes emission of volatile organic matter (VOC) such as hexane which is a hazardous air pollutant. Emission from vegetable oil refining industries is major contributor $(0.7 \mathrm{~kg}$ of hexane per ton of seed) of hexane in air (US EPA, Control of volatile organic emission from manufacture of vegetable oils, 1978). Exposure of hexane at 125ppm for 3 months causes peripheral nerve damage, muscle-wasting, and atrophy (Material safety data sheet for n-Hexane). However, complete removal of hexane might not be possible by evaporation and it remains into the product to an extent. Sometimes, product obtained after solvent extraction is high in free fatty acids (FFA's), waxes, unsaponifiable matter and happens to be of dark greenish-brown color (Juliano, 1985). Therefore, it necessitates and makes refining a critical parameter for final product quality. Also, it is essential that maximum vitamin $\mathrm{E}$, which is naturally present, remains in oil after processing as it prevents oil from oxidizing. Oils with little vitamin $\mathrm{E}$ tend to go rancid quickly unless treated with externally added antioxidant chemicals. Due to all these problems associated with conventional methods of extraction of oil, extensive research and development projects are going on with the ultimate goal of gaining competitive advantage and market share.

Emulsion is a heterogeneous system consisting of at least one immiscible liquid dispersed in another in the form of droplet with the help of surfactant. There are two types of emulsions: oil-in-water $(\mathrm{O} / \mathrm{W})$ (oil is dispersed phase while water is continuous phase) and water-in-oil (W/O) (water is dispersed phase and oil is continuous phase). Depending on the size of the dispersed particles, emulsions can be classified into: macroemulsion (droplet size- 1.5-100 $\mu \mathrm{m}$ ); nanoemulsion (droplet size- 50-500 nm) and microemulsion (droplet size- 3-50 nm) (Windhab et al., 2005; Jafari et al., 2008) (fig. 1). 

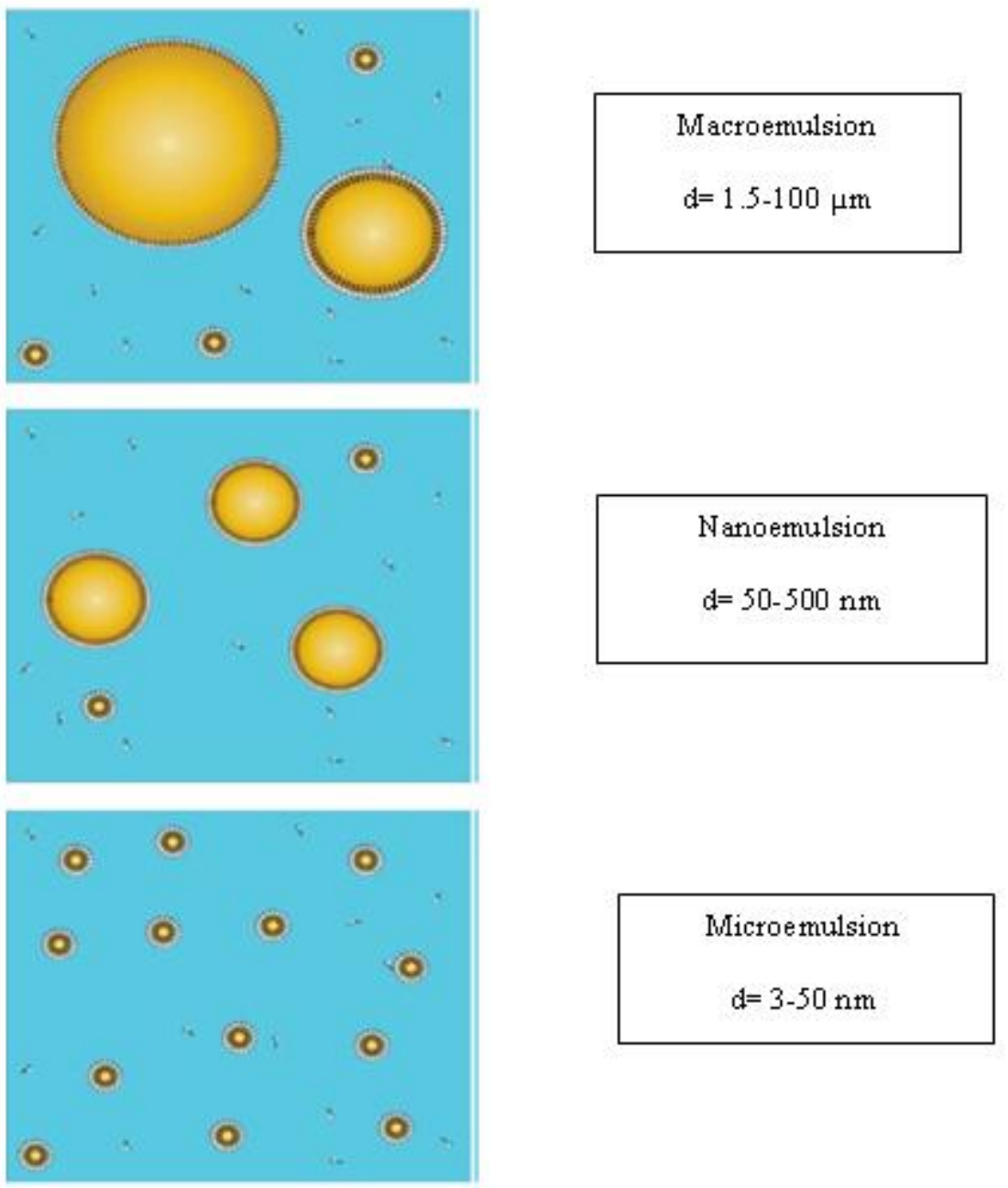

Fig. 1: Schematic representation of emulsion classification (Piorkowski \& McClements, 2013).

Griffin, in the 1940s, (Griffin, 1949, 1954) assigned numerical values to surfactants to classify their behavior and solubility in water. Surfactant is a combination of hydrophilic and lipophilic groups in a single molecule and the weight percentage of these two groups is an indication of the behavior of that surfactant molecule. The HLB value predicts the action of a surfactant, for instance, HLB $<10$ would be good for water-in-oil emulsion whereas HLB $>10$ would be good for oil-in-water emulsion. If $\mathrm{a}_{\mathrm{o}}$ is a relative area of the head group and the $v / l_{c}$ denotes the tail area of surfactant, then

- If $\mathrm{a}_{\mathrm{o}}>\mathrm{v} / \mathrm{l}_{\mathrm{c}}$, then an oil-in-water microemulsion

- If $a_{o}<v / l_{c}$, then a water-in-oil microemulsion

This idea can be more clarified by fig. 2

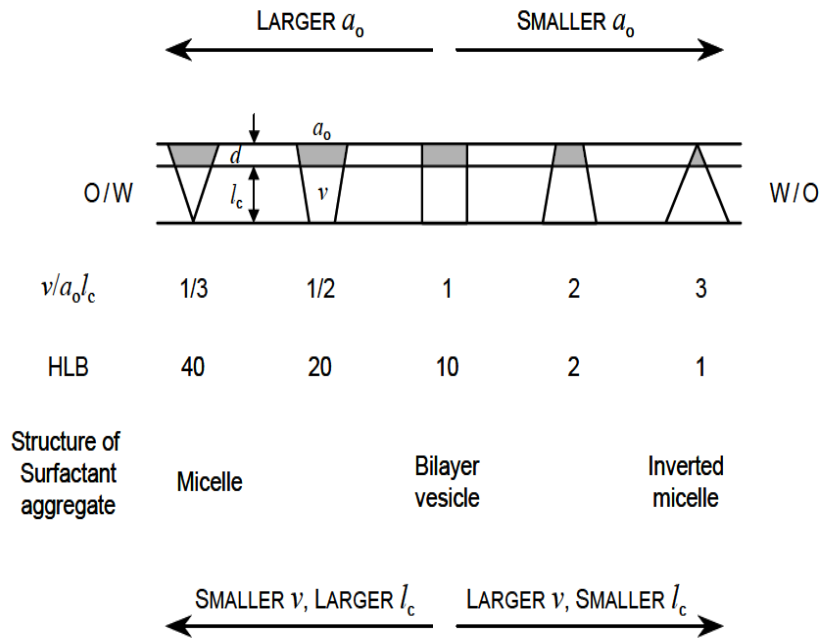

Fig. 2: Effect of HLB number on microemulsion (Israelachvilli, 1994).

Owing to their bio-renewable and nontoxic properties, research interest in vegetable oil based microemulsions has 
increased significantly over the past twenty years. This paper reviews the basic principle of microemulsion and its application in oil extraction. In this paper, we are going to discuss two main topics: i) Principle of microemulsion and ii) Role of microemulsion in oil extraction.

\section{MICROEMULSION}

\subsection{Microemulsion vs Conventional Emulsion}

Microemulsion is a four component system prepared by emulsifying oil in aqueous system with the help of surfactant and co-surfactant. The co-surfactants are generally intermediate chain length alcohols such as pentanol or butanol. Danielsson and Lindman gave one of the best definitions of microemulsions (Danielsson \& Lindman, 1981) "a system consisting of oil, water and an amphiphile (surfactant+co-surfactant), in liquid state, having thermodynamic stability and isotropic property is called microemulsion". Microemulsions are unique from conventional emulsions in many ways, the main distinction being that conventional emulsions are thermodynamically unstable and have finite lifetime after which emulsion breaks. Microemulsions, however, are thermodynamically stable compositions and are formed spontaneously or with gentle agitation once the correct composition is reached. They have potentially infinite lifetimes depending on storage conditions. Other distinctions include droplet size and the color of the system. Conventional emulsions generally have spherical droplets with diameters large enough to scatter white light and are therefore opaque in appearance, whereas microemulsions have droplet sizes of $100 \mathrm{~nm}$ or less and are transparent or have slightly bluish tinge. The key differences between conventional emulsion and microemulsion are summarized in Table 1. Microemulsions can either be oil-in-water, water-in-oil or mixture of these two called bicontinuous phase. Figure 3 illustrates a representation of an $\mathrm{O} / \mathrm{W}$ microemusion droplet.

Table 1: Major differences between microemulsion and conventional emulsion

\begin{tabular}{|l|l|l|l|}
\hline No. & Property & Microemulsion & Conventional Emulsion \\
\hline 1 & Appearance & Transparent & Cloudy \\
\hline 2 & Interfacial Tension & Ultra Low & High \\
\hline 3 & Optical isotropy & Isotropic & Anisotropic \\
\hline 4 & Structure & Dynamic & Static \\
\hline 5 & Droplet size & $3-50 \mathrm{~nm}$ & $1.5-100 \mu \mathrm{m}$ \\
\hline 6 & Stability & Thermodynamically Stable, Long shelf life & $\begin{array}{l}\text { Thermodynamically } \\
\text { Kinetically Stable }\end{array}$ \\
\hline 7 & Phases & Monophasic & Biphasic \\
\hline 8 & Viscosity & Low & High \\
\hline 9 & Preparation & Relatively lower cost for commercial production & $\begin{array}{l}\text { Require a large input of energy, } \\
\text { higher cost }\end{array}$ \\
\hline
\end{tabular}

Surfactant molecule

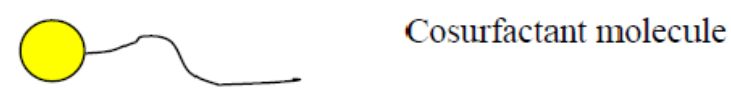

Cosurfactant molecule

Aqueous

phase

Aqueous phase

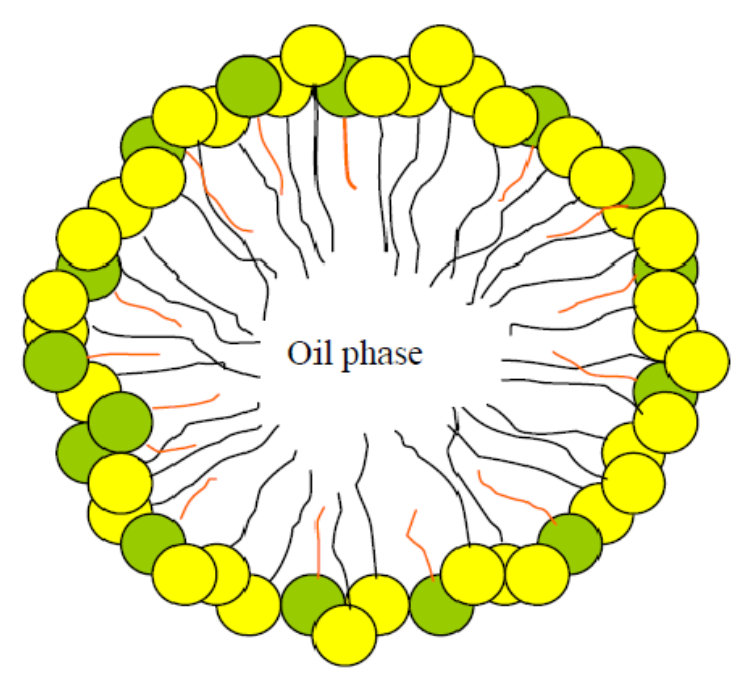

Fig. 3: Cross sectional representation of a spherical O/W microemulsion droplet. 
Nowadays, scientists have been putting more efforts in investigating more applications of microemulsion. Some of its applications are well known and are extensively used, such as, catalysis, submicron particles preparation by microemulsion polymerization, conversion of solar energy and liquid-liquid extraction. Therefore, one should characterize microemulsion structures in detail for improving novel and effective techniques and applications.

\subsection{Main Constituents of Microemulsion}

Microemulsion is a system containing oil, water, surfactant and co-surfactant as major components. A large number of oils and surfactants can be used for microemulsion formulation but their toxicity, unclear mechanism of action, limit their use. The materials should be biocompatible, nonhazardous and safe while using. The emulsifiers should be used in proper proportion that will give amiable and unambiguous microemulsions. To summarize, all the components used to make microemulsion should be considered as generally regarded as safe (GRAS).

The oil component affects curvature due to its ability to penetrate, resulting in swelling the tail (hydrophobic) group region of the surfactant. Short chain oils have higher capacity to penetrate the tail group of surfactant than that of long chain oils. Swelling the tail group results in negative curvature and lessens effective HLB value (Ghosh \& Murthy, 2006).

During microemulsion formulation, surfactant lowers the interfacial tension to very small value and eases the dispersion and produces suitable curvature at the interfacial area. Surfactants having low HLB value $($ HLB $<10)$ is suitable to water-in-oil (W/O) microemulsion whereas those having high HLB value (HLB> 10) is suitable for oil-inwater (O/W) microemulsion (Gadhave, 2014).

Most of the times, surfactants alone are not able to reduce the interfacial tension significantly to enable microemulsion formation (Bhargava, 1987; Kreuter, 1994; Lawrence, 1994; Tenjarla, 1999). Here, co-surfactants play important role by providing significant flexibility to commence various curvatures needed to build microemulsion (Ghosh \& Murthy, 2006; Lawrence \& Rees, 2000; Aboofazeli et al., 1994; Stilbs et al., 1983). These components integrate into interfacial films, but they are not surfactants and don't form micelles on their own. Classical co-surfactants in colloid science are molecules with a small polar head group and an alkyl chain of a suitable length, e.g. n-hexanol, n-pentanol, n-octanol etc. Figure 3 shows orientation of oil, water, surfactant and co-surfactant in oil-in-water (O/W) microemulsion.

\subsection{Microemulsion Classification}

Winsor identified four general types of phase equilibria. On that basis, microemulsion can be classified into four types (Winsor, 1948) which are shown in figure 4.

$>\quad$ Type I: In this type of microemulsions, oil-in-water $(\mathrm{O} / \mathrm{W})$ microemulsion is formed by solubilizing surfactant preferably in water phase. This microemulsion is called "Winsor I" microemulsion. The surfactant-rich water phase accompanies with the oil phase and the surfactant exists as monomer at small concentration.

$>\quad$ Type II: In this type of microemulsions, water-in-oil (W/O) microemulsion is formed by solubilizing surfactant preferably in oil phase. The surfactantloaded oil phase combines with the surfactant-poor aqueous phase. This type of microemulsion is called "Winsor II" microemulsion.

$>\quad$ Type III: Surfactant-loaded middle phase combines with both water and oil phases and forms three phase microemulsion. In this microemulsion, both the water and oil are surfactant-deficient phases. This is also called as "Winsor III".

$>$ Type IV: An isotropic (single micellar) solution is formulated by adding sufficient quantity of surfactant and alcohol (amphiphile) (Winsor IV). A Winsor type IV microemulsion is an extension of a Winsor Type III at higher surfactant concentrations, where the middle phase extends and becomes a single phase.
(1)

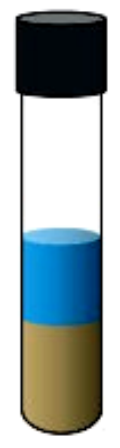

(III)

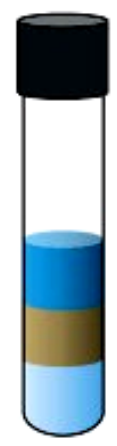

(II)

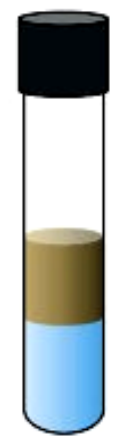

Key: $\square$ Water $\square$ oil $\square$ Microemulsion

Fig. 4: Winsor classification of microemulsion.

\subsection{Phase Diagram Study}

Solubilization and interfacial properties of microemulsions depend on pressure, temperature and nature and concentration of the components (Kahlweit, 1982; Lessner et al., 1983; Sottmann \& Strey, 1997). Therefore, determining the phase stability diagram and position of the various structures formed within these water-oil-surfactantalcohol systems in terms of variables are very important. Brief description of a ternary phase diagram is given below.

\subsubsection{Ternary Phase Diagram}

The ternary phase diagram of a three-component microemulsion, at constant temperature and pressure, is split into two or four regions. The pseudo ternary phase diagram (four component system) is constructed to find the different zones including microemulsion zone as shown in Figure 5. 
The curve (demixing line) in the triangle separates microemulsion and macroemulsion regions. Above demixing line, each composition point is in the single phase region of microemulsion whereas, below demixing line, composition points correspond to multiphase region (two or three-phase region) in equilibrium with very dilute aqueous or organic or both the phases of surfactant. Further, each corner of the diagram represents $100 \%$ of a specific component. If overall composition of any system lies within the two-phase region, it is called as a two-phase system and its compositions are denoted by the "tie-line". This means every point on the tie-line possesses identical coexisting phases of different volumes. If two phases consist of same composition, it is called as a "critical point". The observations should be made carefully to avoid metastable systems (Shafiq-un-Nabi et al., 2007).

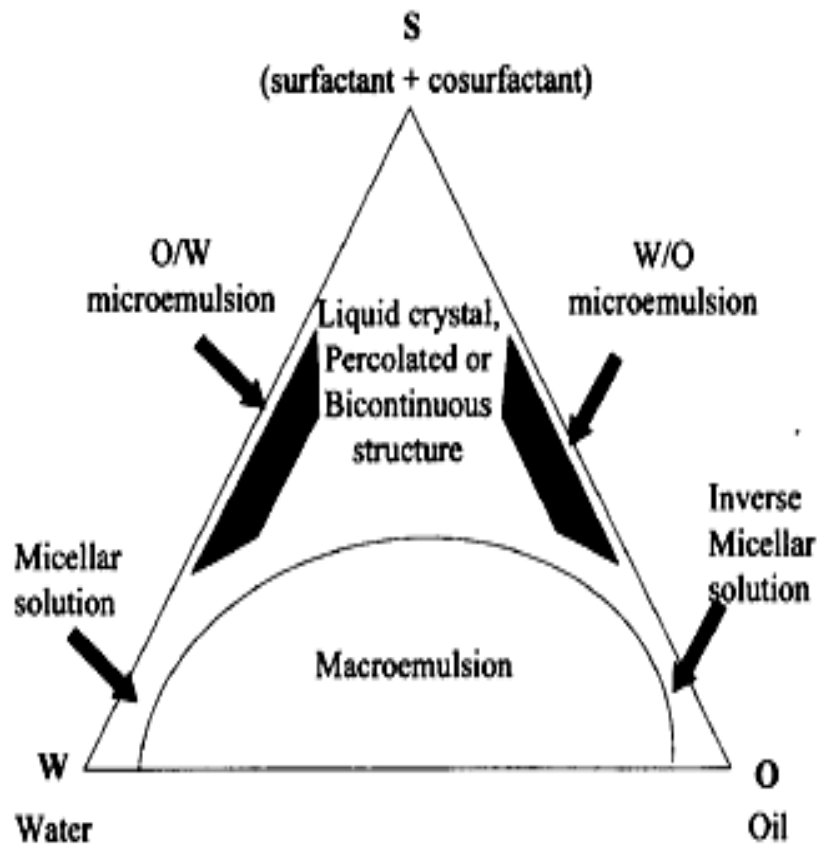

Fig. 5: Schematic presentation of phase diagram of microemulsion. (Patel, 2007)

\subsection{Preparation of Microemulsion}

\subsubsection{Phase Inversion Method}

Phase inversion of microemulsions is formed either by adding excess of dispersed phase (Phase Inversion Concentration) or in response to temperature (Phase Inversion Temperature). The phase inversion method makes drastic physical changes in the system such as changes in particle size.

In phase inversion temperature (PIT) method, the interfacial tension is the key factor. On cooling, the interfacial tension get lowered and can be found in the phase inversion region from water-in-oil (W/O) microemulsion to an oil-in-water $(\mathrm{O} / \mathrm{W})$ microemulsion. In the phase inversion region, this low interfacial tension helps in the spontaneous formation of finely dispersed, blue shining O/W PIT microemulsion. In case of nonionic ethoxylated surfactants, as the temperature increases, their hudrophobicity increases strongly therefore all practical applications of PIT microemulsions are based on the use of ethoxylated surfactants.

Further, changing the water volume fraction causes a transition in the spontaneous radius of curvature. By continuously adding water into oil, initially water droplets are developed in a continuous oil phase. As the water volume increases, the changes occurred in the spontaneous curvature of surfactant causes transition from a W/O microemulsion to an $\mathrm{O} / \mathrm{W}$ microemulsion at the inversion point. Since the phase inversion occurs at definite water concentration within the intermediate microemulsion like phase, the resulting emulsion is called phase inversion concentration (PIC) microemulsion. A bicontinuous microemulsion is formed at the inversion points because of the flexible monolayer of short chain surfactants at the $\mathrm{O} / \mathrm{W}$ interface.

\subsubsection{Phase Titration Method}

Microemulsions are prepared by the spontaneous emulsification method (phase titration method) and can be explained with the help of phase diagram. Construction of the phase diagram is highly recommended to understand the complexity of interactions of different components system that occur due to mixing. Depending on the chemical composition of each component, microemulsions are formed along with various related structures, like emulsions, micelles, lamellar, cubic, hexagonal and different gels and oily dispersions. The knowledge of their phase equilibria and demonstration of the phase boundaries are very important to study which are explained in section 2.4 .

\subsection{Characterization of Microemulsion}

The characterization of microemulsion is a challenging task because of its complexity, variety of structures, components involved in this system and limitations associated with each technique. The physicochemical characterization of microemulsion is mainly based on phase stability, phase behavior, microstructure and dimension (size and size distribution), shape, surface features, local molecular arrangements, interactions and dynamics. Among all these properties, particle size and distribution, their interactions and dynamics are most important as they oversee many of the properties of microemulsions. Therefore, integral studies using a conjugation of techniques are required to get an encyclopedic view of the physicochemical properties. At the microscopic level, viscosity, conductivity and dielectric properties affect the system considerably therefore their analysis is very important to get significant information.

The size distribution of microemulsion is very important to understand the mechanism involving stability and penetration into the membrane (Constantinides \& Yiv, 1995; Mueller et al., 1984). There are many technologies, such as dynamic light scattering (DLS) (Zhang et al., 2013; Porras et al., 2004), small angle neutron scattering (SANS) (Burnett et al., 2004; Silas \& Kaler, 2003; Pedersen, 1999), small angle X-ray scattering (SAXS) (Podlogar et al., 2004; Kawakami 
et al., 2002; Glatter et al., 2001; Kumar \& Mittal, 1999; Solans \& Kuneida, 1997a, 1997b), cryo transmission electron microscopy (Danino et al., 2002a, 2002b; Magdassi et al., 2003); and pulsed field gradient spin echo NMR (Anderson \& Lofroth, 2003; Kreilgaard et al., 2000; Lopez et al., 2004; Koa et al., 2003; Fanun et al., 2001), that are useful to get significant information about size, shape and activity of the components. The major drawback of first three techniques is the dilution of sample required for reduction of interparticular interaction. This dilution alters the structure and constitution of pseudo-phases. However, successful determinations have been carried out using a dilution means that retain droplets identity. The internal photochemical states of microemulsions can be investigated by using several other methods like electrokinetic chromatography, conductance, viscosity, infrared spectroscopy, calorimetry (Kreuter, 1994; Kumar \& Mittal, 1999; Djordjevic et al., 2004; Mrestani et al., 1998; Butani et al., 2014; Moulik \& Paul, 1998).

Conductivity measurement determines whether a microemulsion is oil-continuous or water-continuous. It also provides a means of monitoring phase inversion phenomena (Lawrence \& Rees, 2000). Viscosity measurement signifies the existence of rod-like or worm-like reverse micelles Mehta et al., 1999; Angelico et al., 1998). Dielectric measurements are used to provide structural and dynamic characteristics of microemulsions. The Fourier transform pulsed-gradient spin echo (FT-PGSE) method builds the magnetic gradient on the samples. This facilitates concurrent and rapid determination of the self-diffusion coefficients (range $10^{-9}$ to $10^{-12} \mathrm{~m}^{2} \mathrm{~s}^{-1}$ ) of many components (Shinoda et al., 1991; Corswant \& Soderman, 1998).

\section{ROLE OF MICROEMULSION IN OIL \\ EXTRACTION}

Industry calls for a safer and efficient process because of the problems (discussed in introduction) incurred in conventional method of oil extraction, to which Green Nanotechnology could be an answer (Raman et al., 2003; Komesvarakul et al., 2006; Do et al., 2009). Their principle focus is formation of environmentally friendly emulsifier based constitutions that retains the simplicity of operation and lowers the energy consumption while maintaining performance. Hence, aqueous-based biocompatible microemulsions could be the replacement for hexane. The ultralow interfacial tension is very important property for a surfactant based system to be used in extraction of oil since it promotes both collection (roll up) and quick removal (snap-off) means of oil from the oil-seed.

\subsection{Principle of Oil Extraction by Microemulsion}

Microemulsions possess nano-sized aggregates that could be used as 'receptors' for extracting specific molecules at a nanoscale level (Witthayapanyanon et al., 2005). Since microemulsions contain droplet sizes of 1-100 nanometer (nm) scale, they can be considered "small" vessels or nanophases for conducting reactions (Acosta et al., 2005).
They have capacity to solubilize both water and oil soluble compounds (Paul \& Moulik, 2001). The extraction of oil from oilseeds by microemulsion (water/surfactant/cosurfactant) system involves solubilization and incorporation of oil into the micelles and builds oil-in-water or bicontinuous microemulsion (Solans \& Kunieda, 1997; Furan, 2009). In aqueous based extraction, water soluble components of oil seeds are dissolved resulting in release of oil bound to the cell structure (Johnson \& Lusas, 1983). Here, water is the continuum phase and oil gets trapped in the hydrophobic core of the micelles. The extent of solubilization and extraction of oil in premix (a mixture of known quantities of surfactant, co-surfactant and water) can be obtained from the phase diagram. It is equal to the percentage of oil at the boundary of one-phase microemulsion area along the corresponding dilution line of the premix. Once the oil is trapped in premix, it is very unlikely to get released from micelle structure (Acosta et al., 2005).

The oil extraction efficiency is analyzed by HPLC method and then calculated by following equation 1 .

$$
\% \text { oil extraction }=\frac{\text { Weight of extracted oil }}{\text { Weight of total oil in raw seeds }} \times 100
$$

Extraction efficiencies of these microemulsions are very similar to that for hexane extraction (Naksuk et al., 2009) which is shown by Fig 6 .

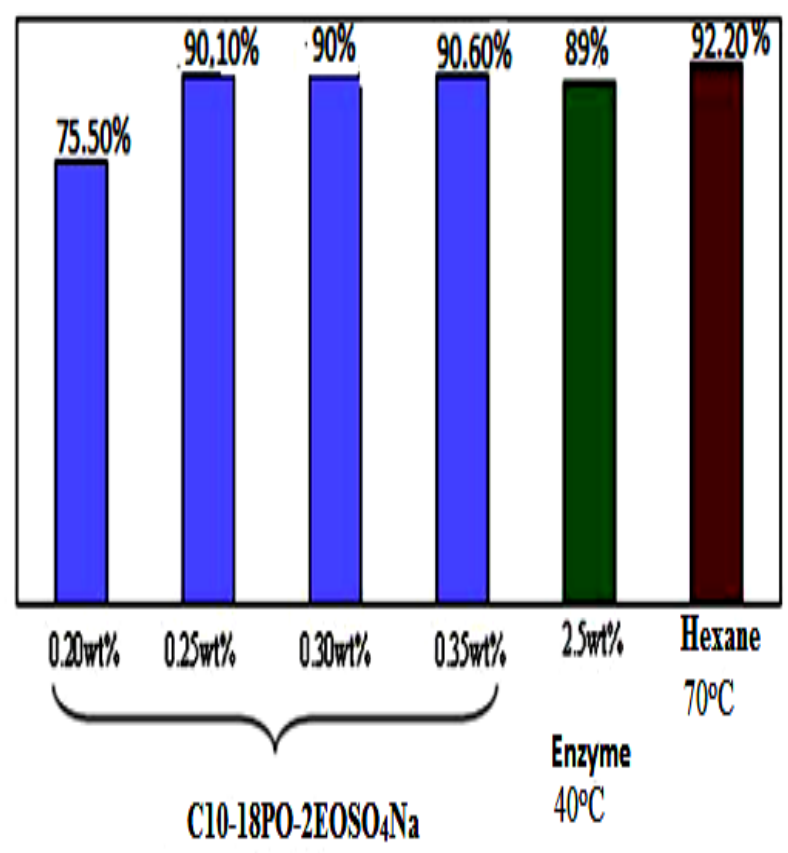

Fig. 6 Comparison of oil (peanut) extraction between microemulsion and solvent extraction techniques (Witthayapanyanon \& Do, Retrieved 2014) 


\subsection{Effect of Operating Parameters on Extraction}

\section{Efficiency}

Emulsion based vegetable oil extraction consists of the removal of the oil from solid oilseed to the liquid phase. There are various parameters involve in oil extraction. These parameters are contact time between oilseeds and the solvent, shaking time, the extraction temperature and solid to solvent ratio. There should be a sufficient contact time for solvent to interact with the oilseeds and make most efficient extraction of the oil. Temperature pushes the rate of extraction at which solid and solvent form equilibrium. Shaking time improves the contact area of solids with the solvent and thus increases the extraction of oil.

\subsection{Importance of Linkers in Oil Extraction}

Sometimes, when ambient conditions are not favorable for microemulsion formation by using only extended surfactants, linkers could be incorporated in the system along with them to give better results (Do et al., 2009).

Linkers, with the help of surfactants, lower interfacial as well as surface tension drastically. Hydrophilic and lipophilic linkers (e.g. hexyl polyglucoside and sorbitan monoleate respectively) along with the surfactant (e.g. lecithin) decrease the surface tension. This facilitates microemulsion formation and hence the oil extraction (Acosta et al., 2004, 2005). Linkers, unlike co-surfactants which have tendency to get adsorbed at the oil-water interface, show unique behavior in a microemulsion. Lipophilic linkers are amphiphilic molecules such as fatty alcohols, acids or amines and segregate near the surfactant tails, deeper into the oil side of the interface (Bourrel \& Schechter, 1988). Hydrophilic linkers, on the other hand, with a short hydrophobe and a strong hydrophile, have ability to co-adsorb partially with the surfactant expanding the interfacial area. However, they do not interact substantially with the oil phase (Acosta et al., 2002). Both of these linkers combine at the interface in presence of a surfactant which allow their segregation and form 'selfassembled' structures which have surfactant like properties (Acosta et al., 2004). This reduces the amount of expensive surfactant needed for extraction (Sabatini et al., 2003). Further, oil extraction through microemulsion can be facilitated by using 'extended surfactants' (Witthayapanyanon et al., 2006). These contain one or more intermediate-polarity groups (ethoxylate and/or propoxylate) between the hydrophilic head and the hydrophobic tail hence cause extension of latter. This extended tail segregates further into the oil phase without sacrificing the water solubility (Salager et al., 2005). This unique structure of extended surfactants allows them to achieve ultralow interfacial tension (IFT) as low as $10^{-3} \mathrm{mN} / \mathrm{m}$ with a wide range of oils.

\subsection{Effect of Temperature}

Temperature is also one of the most important parameters affecting extraction of oil through microemulsion. The solubilization and extraction of the oil increase with increase in temperature. This can be explained by phase diagram (Fig. 7). The figure depicts the one phase microemulsion areas of oil/surfactant:co-surfactant/water systems are increased with increasing the temperature (Radi et al., 2013). This is a key factor for the solubilization of oil from oilseeds. The premix of microemulsion (a mixture of known quantities of surfactant, co-surfactant and water) can solubilize a definite quantity of oil and produce one phase microemulsion at respective temperatures. The solubilization of oil into premix of microemulsion is directly proportional to the temperature. Hence, the precaution should be taken in selecting a system having high capacity of oil solubilization at higher temperature with restricting the formation of microemulsion at lower temperature. This means the one phase microemulsion which is formed by solubilization of extracted oil at elevated temperature should get destabilized at lower temperature (cooling) and get converted into multiphase microemulsion system. This multiphase microemulsion has no ability of holding the oil and thus separation of extracted oil from the system takes place.

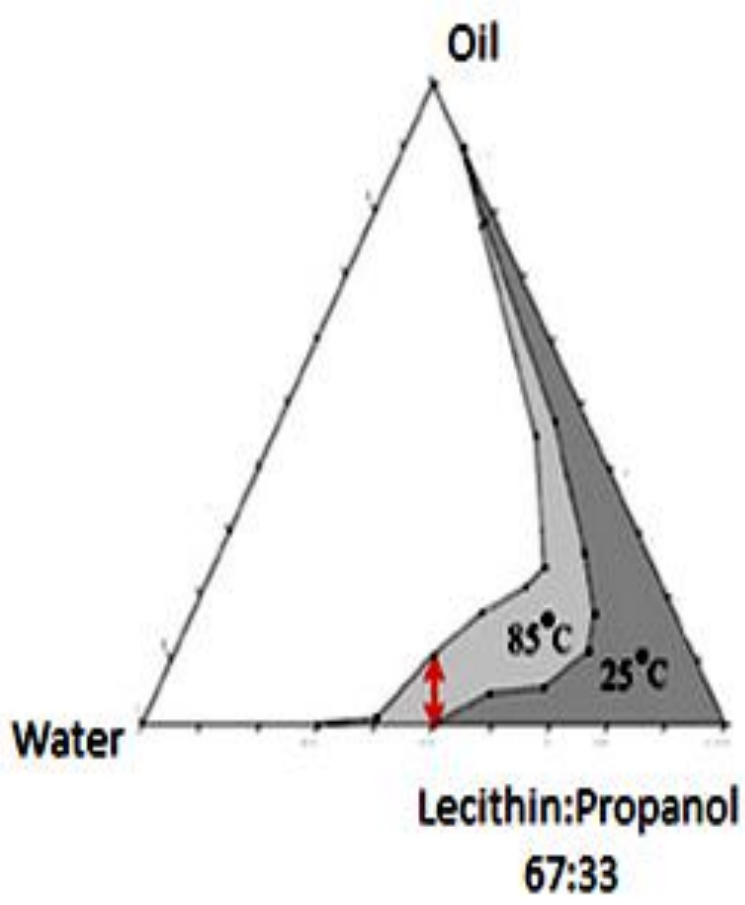

Fig. 7: The relation between temperature and oil solubilization capacity of microemulsion. The arrow shows the capacity for extraction of oil from oilseed (Radi et al., 2013).

Table 2 shows the scope of Microemulsion assisted oil extraction as studied by some researchers. 
Table 2: Microemulsion assisted oil extraction.

\begin{tabular}{|c|c|c|c|c|}
\hline Oil extracted & $\begin{array}{l}\text { Microemulsion } \\
\text { based on }\end{array}$ & Linkers/Extended surfactant & Conclusions & References \\
\hline $\begin{array}{l}\text { Hexadecane (as } \\
\text { a model oil) } \\
\text { from cotton } \\
\text { fabric }\end{array}$ & $\begin{array}{l}\text { Surfactant }+ \\
\text { Linkers }\end{array}$ & $\begin{array}{l}\text { hexyl } \\
\text { polyglucoside, sorbitan monoleate }\end{array}$ & $\begin{array}{l}\text { Linkers based microemulsion } \\
\text { are potential substitute for } \\
\text { organic solvents in dry } \\
\text { cleaning }\end{array}$ & $\begin{array}{l}\text { (Acosta et } \\
\text { al., 2005) }\end{array}$ \\
\hline Corn oil & $\begin{array}{l}\text { Extended } \\
\text { surfactant }\end{array}$ & $\begin{array}{l}\text { sodium linear-alkyl polypropoxylated } \\
\text { polyethoxylated sulfates }\end{array}$ & $\begin{array}{l}>80 \% \text { extraction could be } \\
\text { achieved with only } 0.4 \% \\
\text { surfactant }\end{array}$ & $\begin{array}{l}\text { (Kadioglu } \\
\text { et al., 2011) }\end{array}$ \\
\hline Peanut oil & $\begin{array}{l}\begin{array}{l}\text { Extended } \\
\text { surfactant }\end{array} \\
\end{array}$ & $\begin{array}{l}\text { Rhamnolipid, Sophorolipid, Sodium bis(2- } \\
\text { ethyl) dihexyl sulfosuccinate (SBDHS) }\end{array}$ & $\begin{array}{l}\text { Single step extraction for } 10 \\
\text { mins with } 95 \% \text { efficiency }\end{array}$ & $\begin{array}{l}\text { (Nguyen et } \\
\text { al., 2010) }^{\mathrm{a}}\end{array}$ \\
\hline Palm kernel oil & $\begin{array}{l}\text { Extended } \\
\text { surfactant }\end{array}$ & Comperlan KD, Alfoterra145-5PO/8PO & 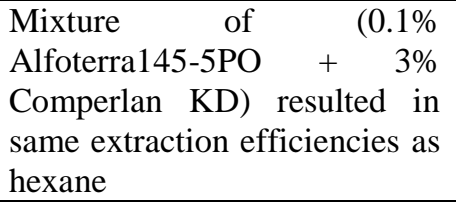 & $\begin{array}{l}\text { (Naksuk et } \\
\text { al., 2009) }\end{array}$ \\
\hline $\begin{array}{l}\text { Canola and } \\
\text { peanut oil }\end{array}$ & $\begin{array}{l}\text { Extended } \\
\text { surfactant }\end{array}$ & C10-18PO-2EOsulfate (APES type) & $\begin{array}{l}0.15 \% \text { and } 0.30 \% \text { surfactant } \\
\text { liberated } 95 \% \text { of free peanut } \\
\text { oil and } 93 \% \text { canola oil } \\
\text { respectively, FFA's decreased } \\
\text { by } 94 \% \text { as compared to } \\
\text { hexane extracted samples }\end{array}$ & $\begin{array}{l}\text { (Do \& } \\
\text { Sabatini, } \\
\text { 2010) }\end{array}$ \\
\hline Mustard oil & $\begin{array}{l}\text { Reverse micellar } \\
\text { (RM) extraction }\end{array}$ & $\begin{array}{l}\text { Cetyltrimethylammonium } \\
\text { (CTAB) }\end{array}$ & $\begin{array}{l}\text { Simultaneous extraction of oil } \\
\text { and soluble protein with } 90 \% \\
\text { recovery of latter }\end{array}$ & $\begin{array}{l}\text { (Ugolini et } \\
\text { al., 2008) }\end{array}$ \\
\hline N.A & $\begin{array}{l}\text { Extended } \\
\text { surfactant } \\
\text { linkers }\end{array}$ & $\begin{array}{l}\text { Linear alkyl polypropoxylated ethoxylated } \\
\text { sulfate (LAPES), oleyl alcohol (lipophilic } \\
\text { linker), sodium mono- and dimethyl } \\
\text { naphthalene sulfonate, (SMDNS) and } \\
\text { polyglucoside (hydrophilic linkers) }\end{array}$ & $\begin{array}{l}\text { Bicontinuous microemulsions }{ }^{\mathrm{c}} \\
\text { with high oil solubilization (up } \\
\text { to } 10 \mathrm{ml} / \mathrm{mg} \text { ) regardless of } \\
\text { triglyceride composition }\end{array}$ & $\begin{array}{l}\text { (Do et al., } \\
2009)^{d}\end{array}$ \\
\hline
\end{tabular}

a. Study used biosurfactant facilitated diesel-based microemulsion.

b. Reverse micelles posses hydrophilic core with hydrophobic tail pointing outwards. This extraction technique requires some concentrations of organic solvent (e.g. hexane, isooctane, or cyclohexane) to form desired suspension.

c. These are microemulsions containing both normal and reverse micelles dispersed equally, having potential of extracting both water and oil soluble component.

d. Though studies aim at formulating various types (Winsor I, II, III and IV) of microemulsions at ambient temperature, the technique can be extended for extraction purpose.

\subsection{Advantages of Microemulsion in Oil Extraction}

$>$ Process avoids use of any hazardous organic solvents for oil extraction; hence it is a relatively 'Clean Approach' (Naksuk et al., 2009).

$>$ Efficient at room temperatures.

D Low surfactant concentrations needed to achieve high efficiencies.

$>$ Less process (extraction) time.
$>$ Simultaneous recovery of oil and protein is possible with low initial costs.

$>$ Evaporation is replaced by centrifugation for oilsolvent separation, therefore decreasing the operating cost to a large extent. Good quality oil without any burnt flavor which is present in solvent extracted product as a result of heating to recover hexane.

\section{CONCLUSIONS}

The current review presents microemulsion as an alternative approach in oil extraction system. It provides one of the most promising systems to improve solubility, bioavailability and functionality of hydrophobic compounds. It would be the best alternative to conventional VOCs/solvent extraction method.

Microemulsion contains nano-sized agglomerates that help in extracting of oil at nanoscale levels. This process operates at room temperature so no extra energy is required while conventional extraction methods operate at elevated temperature and thus, consume large amount of energy. This technique is very effective even at low surfactant concentration. The quantity of oil extracted by this method is almost same as that of solvent extraction method. Further, it is possible to recover oil as well as protein 
without compromising their quality with the help of microemulsion technology. Separation of oil-solvent is done by centrifugation rather evaporation, thereby decreasing the operating costs.

Hence, microemulsion technology would be more economic, efficient, convenient and flexible approach, in oil extraction technique, in comparison to solvent extraction method and would fulfill the needs of oilseed industry.

\section{REFERENCES}

[1] Aboofazeli R, Lawrence C B, Wicks S R \& Lawrence M J. (1994). Investigations into the formation and characterization of phospholipid microemulsions III. Pseudo-ternary phase diagrams of systems containing water-lecithin-isopropyl myristate and either an alkanoic acid, amine, alkanediol, poly ethylene glycol alkyl ether or alcohol as co-surfactant. International Journal of Pharmaceutics. 111(1), 63-72. DOI: 10.1016/03785173(94)90402-2.

[2] Acosta E J, Harwell J H \& Sabatini D A. (2004). Self-assembly in linker-modified microemulsions. Journal of Colloids and Interface Science. 274(2), 652-664. DOI: 10.1016/j.jcis.2004.03.037.

[3] Acosta E, Uchiyama H, Sabatini D. A. \& Harwell J. H. (2002). The role of hydrophilic linkers. Journal of Surfactants and Detergents. 5(2), 151-157. DOI: 10.1007/s11743-002-0215-z.

[4] Acosta E J. Nguyen T, Witthayapanyanon A, Harwell J H \& Sabatini D A. (2005). Linker-based bio-compatible microemulsions. Environmental Science and Technology. 39(5), 1275-1282. DOI: $10.1021 / \mathrm{es} 049010 \mathrm{~g}$.

[5] Agilent Technology. Material Safety Data Sheet for n-Hexane. Retrieved 15 Nov. 2013 from www.chem.agilent.com/Library/msds/200-0007.pdf.

[6] Andersson M \& Lofroth J -E. (2003). Small particles of a heparin/chitosan complex prepared from a pharmaceutically acceptable microemulsion. International Journal of Pharmaceutics. 257(1-2), 305-309. DOI: 10.1016/S0378-5173(03)00131-5.

[7] Angelico R, Palazzo G, Colafemmina G, Cirkel PA, Giustini M \& Ceglie A. (1998). Water diffusion and head group mobility in polymer like reverse micelles: evidence of a sphere to rod to sphere transition. The Journal of Physical Chemistry $B$. 102(16), 2883-2889. DOI: 10.1021/jp980194t.

[8] Bhargava H N, Narurkar A \& Lieb L M. (1987). Using microemulsions for drug delivery. Pharm. Technol. 11, 46-52.

[9] Bourrel M, Schechter R (1988) Microemulsions and Related Systems. Marcel Dekker, New York.

[10] Burnett G R, Rees G D, Steytler D C \& Robinson B H. (2004). Fluorescence correlation spectroscopy of water-in-oil microemulsions: an application in specific characterization of droplets containing biomolecules. Colloids and Surfaces A: Physicochemical and Engineering Aspects. 250(13), 171-178. DOI: 10.1016/j.colsurfa.2004.05.025.
[11] Butani D, Yewale C \& Misra A. (2014). Amphotericin B topical microemulsion: formation, characterization and evaluation. Colloids and Surfaces B: Biointerfaces. 116, 351-358. DOI: 10.1016/j.colsurfb.2014.01.014.

[12] Constantinides P P \& Yiv S H. (1995). Particle size determination of phaseinverted water-in-oil microemulsions under different dilution and storage conditions. International Journal of Pharmaceutics. 115(2), 225-234. DOI: $10.1016 / 0378-$ 5173(94)00272-7.

[13] Corswant C V \& Soderman O. (1998). Effect of adding isopropyl myristate to microemulsions based on soybean phosphatidylcholine and triglycerides. Langmuir. 14(13), 3506-3511. DOI: $10.1021 / 1 \mathrm{a} 971248 \mathrm{~d}$.

[14] Danielsson I \& Lindman B. (1981). The definition of microemulsion. Colloids and Surfaces A: Physicochemical and Engineering Aspects. 3(4), 391-392. DOI: 10.1016/0166-6622(81)80064-9.

[15] Danino D, Gupta R, Satyavolu J \& Talmon Y. (2002). Direct Cryogenic temperature transmission electron microscopy imaging of phospholipids aggregates in soybean oil. Journal of Colloid and Interface Science. 249(1), 180-186. DOI: 10.1016/S0927-7757(00)00418-0.

[16] Danino D, Talmon Y \& Zana R. (2002). Cryo-TEM of thread like micelles: on the grid microstructural transformations induced during specimen preparation. Colloids and Surfaces A: Physicochemical and Engineering Aspects. 169(13), 67-73. DOI: 10.1016/S0927-7757(00)00418-0.

[17] Djordjevic L, Primorac M, Stupar M \& Krajisnik D. (2004). Characterization of caprylocaproyl macrogolglycerides based microemulsion drug delivery vehicles for an amphiphilic drug. International Journal of Pharmaceutics. 271(1-2), 11-19. DOI: 10.1016/j.ijpharm.2003.10.037.

[18] Do L, Witthayapanyanon A, Harwell J \& Sabatini DA. (2009). Environmentally friendly vegetable oil microemulsions using extended-surfactants and linkers. Journal of Surfactants and Detergents. 12(2). 91-99. DOI: 10.1007/s11743-008-1096-0.

[19] Do LD \& Sabatini DA. (2010). Aqueous extendedsurfactant based method for vegetable oil extraction: proof of concept. Journal of American Oil Chemists' Society. 87(10), 1211-1220. DOI: 10.1007/s11746010-1603-0.

[20] Fanun M, Wachtel E, Antalek B, Aserin A, Hoffman RE \& Garti N. (2001). A study of the microstructure of four-component sucrose ester microemulsions by SAXS and NMR. Colloids and Surfaces A: Physicochemical and Engineering Aspects. 180(12), 173-186. DOI: 10.1016/S0927-7757(00)00744-5.

[21] Furan M (Ed) (2009) Microemulsions: properties and applications. Surfactant Science Series. 144, 187.

[22] Gadhave A. (2014). Determination of hydrophiliclipophilic balance value. International Journal of Science and Research. 3(4), 573-575. 
[23] Ghosh P K \& Murthy R S. (2006). Microemulsion: A potential drug delivery system. Current Drug Delivery. 3(2), 167-180.

[24] Glatter O, Orthaber D, Stradner A, Scherf G, Fanun M, Garti N, Clement V, Leser ME (2001) Sugarester non-ionic microemulsion: Structural characterization. Journal of Colloid and Interface Science. 241(1), 215-225. DOI: 10.1006/jcis.2001.7670.

[25] Griffin W C. (1949). Classification of SurfaceActive Agents by "HLB". Journal of the Society of Cosmetic Chemists. 1, 311-326.

[26] Griffin W C. (1954). Calculation of HLB values of non-ionic surfactants. Journal of the Society of Cosmetic Chemists. 5, 249-256.

[27] Israelachvilli J. (1994). The science and applications of emulsions-an overview. Colloids and Surfaces A: Physicochemical and Engineering Aspects. 91, 1-8. DOI: 10.1016/0927-7757(94)02743-9.

[28] Jafari S M, Assadpoor E, He Y \& Bhandari B. (2008). Re-coalescence of emulsion droplets during high energy emulsification. Food Hydrocolloids. 22(1), 191-202. DOI: 10.1016/j.foodhyd.2006.10.012.

[29] Jian X, Ganzuo L, Zhiqiang Z, Guowei Z \& Kejian J. (2001). A study of the microstructure of CTAB/1butanol/octane/water system by PGSENMR, conductivity and cryo-TEM. Colloids and Surfaces A: Physicochemical and Engineering Aspects. 191(3), 269-278. DOI: 10.1016/S09277757(01)00689-6.

[30] Johnson LA \& Lusas EW. (1983). Comparison of alternative solvents for oils extraction. Journal of American Oil Chemists' Society. 60(2), 229-242. 10.1007/BF02543490.

[31] Juliano B O. (1985). Rice: chemistry and technology, (2nd Ed.) (pp.774). The American Assoc. Cereal Chem. St. Paul, Minnesota.

[32] Kadioglu SI, Phan TT \& Sabatini DA. (2011). Surfactant-based oil extraction of corn germ. Journal of American Oil Chemists' Society. 88(6), 863-869. DOI: 10.1007/s11746-010-1719-2.

[33] Kahlweit M. (1982). The phase behavior of systems of the type $\mathrm{H}_{2} \mathrm{O}$-oil-nonionic surfactant-electrolyte. Journal of Colloid and Interface Science. 90(1), 197-202. DOI: 10.1016/0021-9797(82)90412-X.

[34] Kawakami K, Yoshikawa T, Moroto Y, Kanaoka E, Takahashi K, Nishihara Y \& Masuda K. (2002). Microemulsion formulation for enhanced absorption of poorly soluble drugs: I. Prescription design. Journal of Controlled Release. 81(1-2), 65-74. DOI: 10.1016/S0168-3659(02)00049-4.

[35] Koa C J, Kob Y J, Kim D M \& Park H J. (2003). Solution properties and PGSE-NMR self-diffusion study of C18:1 E10/oil/water system. Colloids and Surfaces A: Physicochemical and Engineering Aspects. 216(1-3), 55-63. DOI: 10.1016/S09277757(02)00497-1.

[36] Komesvarakul N, Szekeres SE, Acosta EJ, Faller JF, Mentlik T, Fisher LB, Nicoll G, Sabatini DA \&
Scamehorn JF. (2006). Microemulsions of triglyceride-based oils: the effect of co-oil and salinity on phase diagrams. Journal of Cosmetic Science. 55(4), 309-325.

[37] Kreilgaard M, Pedersen E J \& Jaroszewski J W. (2000). NMR characterization and transdermal drug delivery potential microemulsion systems. Journal of Controlled Release. 69(3), 421-433. DOI: 10.1016/S0168-3659(00)00325-4.

[38] Kreuter J. (1994) In: Colloidal drug delivery systems, Microemulsions (pp 31-71). Marcel Dekker, New York.

[39] Kumar P \& Mittal K L. (1999). Microemulsions in foods; In: Handbook of Microemulsion Science and Technology (pp 789). Marcel Dekker, New York.

[40] Lawrence M J \& Rees G D. (2000). Microemulsion based media as novel drug delivery systems. Advanced Drug Delivery Reviews. 45(1), 89-121. DOI: 10.1016/S0169-409X(00)00103-4.

[41] Lawrence M J. (1994). Surfactant systems: microemulsions and vesicles as vehicles for drug delivery. European Journal of Drug Metabolism and Pharmacokinetics. 19(3), 257-269. DOI: 10.1007/BF03188929.

[42] Lessner E, Kahlweit M \& Strey R. (1983). Influence of the properties of the oil and the surfactant on the phase behavior of systems of the type $\mathrm{H}_{2} \mathrm{O}$-oilnonionic surfactant. Journal of Physical Chemistry. 87, 5032-5040. DOI: 10.1021/j150642a051.

[43] Lopez F, Cinelli G, Ambrosone L, Colafemmina G, Ceglie A \& Palazzo G. (2004). Role of the cosurfactant in water-in-oil microemulsion: interfacial properties tune the enzymatic activity of lipase. Colloids and Surfaces A: Physicochemical and Engineering Aspects. 237(1-3), 49-59. DOI: 10.1016/j.colsurfa.2004.01.027.

[44] Magdassi S, Ben Moshe M, Talmon Y \& Danino D. (2003). Microemulsion based on anionic Gemini surfactant. Colloids and Surfaces A: Physicochemical and Engineering Aspects. 212(1), 1-7. DOI: 10.1016/S0927-7757(02)00294-7.

[45] Mattil KF \& Norris FA. (1964) Bailey's Industrial Oil and Fat Products. ( $3^{\text {rd }}$ ed.). Swern D. (Eds.). Extraction of fats and oils. (pp 637-717). John Willey \& Sons, London.

[46] Mehta S K, Kavaljit X X \& Bala K. (1999). Phase behaviour, structural effects, volumetric and transport properties in non-aqueous microemulsions. Physical Reviews. E-59, 4317-4325. DOI: http://dx.doi.org/10.1103/PhysRevE.59.4317.

[47] Moulik SP \& Paul BK. (1998). Structure, dynamics and transport properties of microemulsions. Advances in Colloid and Interface Science. 78(2), 99-195. DOI: 10.1016/S0001-8686(98)00063-3.

[48] Mrestani Y, El-Mokdad N, Ruttinger H H \& Neubert RHH. (1998). Characterization of partitioning behaviour of cephalosporins using microemulsion and micellar electrokinetic chromatography. Electrophoresis. 19(16-17), 28952899. 
[49] Mueller B W \& Mueller R H. (1984). Particle size distributions and particle size alterations in microemulsions. Journal of Pharmaceutical Sciences. 73(7), 919-922. DOI: $10.1002 / j p s .2600730714$.

[50] Naksuk A, Sabatini D A \& Tongcumpou C. (2009). Microemulsion-based palm oil extraction using mixed surfactant solutions. Industrial Crops and Products. 30(2), 194-198. DOI: 10.1016/j.indcrop.2009.03.008.

[51] Nguyen T, Do 1 \& Sabatini D A. (2010) Biodiesel production via peanut oil extraction using dieselbased reverse-micellar microemulsion. Fuel. 89(9), 2285-2291. DOI: 10.1016/j.fuel.2010.03.021.

[52] Patel M R. (2007). Microemulsions: As novel drug delivery vehicle. Pharmaceutical Information, Articles and Blogs. Retrieved 22 ${ }^{\text {nd }}$ March 2014 from http://www.pharmainfo.net/reviews/microemulsions -novel-drug-delivery-vehicle.

[53] Paul B K \& Moulik S P. (2001). Uses and applications of microemulsions. Current Science. 80(8), 990-1001.

[54] Pedersen J S. (1999). Analysis of small-angle scattering data from micelles and microemulsions: Free-form approaches and model fitting. Current Opinion in Colloid and Interface Science. 4(3), 190196. DOI: 10.1016/S1359-0294(99)00033-3.

[55] Piorkowski D T \& McClements D J. (2013). Beverage emulsions: Recent developments in formulation, production and applications. Food Hydrocolloids.

http://dx.doi.org/10.1016/j.foodhyd.2013.07.009.

[56] Podlogar F, Gasperlin M, Tomsic M, Jamnik A \& Bester Rogac M. (2004). Structural characterisation of water-Tween 40®/Inwitor 308®isopropylmyristate microemulsions usinf different experimental methods. International Journal of Pharmaceutics. 276(1-2), 115-128. DOI: 10.1016/S0168-3659(02)00049-4.

[57] Porras M, Solans C, Gonzalez, C, Martinez A, Guinart A \& Gutierrez, J M. (2004). Studies of formation of w/o nanoemulsions. Colloids and Surfaces A: Physicochemical and Engineering Aspects. 249(1-3), 115-118. DOI: 10.1016/j.colsurfa.2004.05.025.

[58] Radi M, Abbasi S, Hamidi Z \& Azizi M -H. (2013). Development of a new method for extraction of conola oil using lecithin based microemulsion systems. Food Technology. 24(5). 70-72.

[59] Raman I A, Suhaimi H \& Tiddy G J T. (2003). Liquid crystals and microemulsion formed by mixture of a non-ionic surfactant with palm oil and its derivatives. Advances in Colloid and Interface Science. 106(1-3), 109-127. DOI: 10.1016/S00018686(03)00107-6.

[60] Sabatini D A, Acosta E \& Harwell J H. (2003), Linkers molecules in surfactant mixtures. Current Opinion in Colloid and Interface Science. 8(4-5), 316-326. DOI: 10.1016/S1359-0294(03)00082-7.
[61] Salager J L, Anton R E, Sabatini D A, Harwell J H, Acosta E J \& Tolosa L I. (2005). Enhancing solubilization in microemulsions state of the art and current trends. Journal of Surfactants and Detergents. 8(1), 3-21. DOI: 10.1007/s11743-0050328-4.

[62] Shafiq-un-Nabi S, Shakeel F, Talegaonkar S, Ali J, Baboota S, Ahuja A, Khar R K \& Ali M. (2007). Formulation development and optimization using nanoemulsion technique: A technical note. AAPS Pharm SciTech. 8(2), E12-E17. DOI: 10.1208/pt0802028.

[63] Shinoda K, Araki M, Sadaghiani A, Khan A \& Lindman B. (1991). Lecithin-based microemulsions: phase behavior and microstructure. Journal of Physical Chemistry. 95(2), 989-993. DOI: $10.1021 / \mathrm{j} 100155 \mathrm{a} 091$.

[64] Silas J A \& Kaler E W. (2003). Effect of multiple scattering on SANS spectra from bicontinuous microemulsions. Journal of Colloid and Interface Science. 257(2), 291-298. DOI: 10.1016/S13590294(99)00033-3.

[65] Snape J B \& Nakajima M. (1996). Processing of agricultural fats and oils using membrane technology. Journal of Food Engineering. 30(1-2), 1-41. DOI: 10.1016/S0260-8774(96)00053-2.

[66] Solans C \& Kuneida H. (1997). In: Industrial Applications of Microemulsions, Microemulsions in the pharmaceutical field: perspectives and applications (pp 98-120). Marcel Dekker, New York.

[67] Solans C \& Kuneida H. (Eds), (1997). In: Industrial applications of microemulsions, Microemulsions in foods: Properties and applications. (pp 148). Marcel Dekker, New York.

[68] Solans C \& Kunieda H (Eds). (1997) Industrial applications of microemulsions. Marcel Dekker, New York, 66: 1-23.

[69] Sottmann T \& Strey R. (1997). Ultralow interfacial tensions in water-n-alkane-surfactant systems. Journal of Chemical Physics. 106(20). http://dx.doi.org/10.1063/1.473916.

[70] Stilbs P, Lindman B \& Rapacki K. (1983). Effect of alcohol co-surfactant length on microemulsion structure. Journal of Colloid and Interface Science. 95(2), 583-585. DOI: 10.1016/0021-9797(83)902175.

[71] Tenjarla S. (1999). Microemulsions: an overview and pharmaceutical applications. Critical Reviews in Therapeutic Drug Carrier Systems. 16(5), 461-521.

[72] U. S. Environmental Protection Agency. (1978). Control of Volatile Organic Emissions From Manufacture Of Vegetable Oils, EPA-450/2-78-035, North Carolina.

[73] Ugolini L, Nicola GD \& Palmieri S. (2008) Use of reverse micelles for the simultaneous extraction of oil, proteins, and glucosinolates from cruciferous oilseeds. Journal of Agriculture and Food Chemistry. 56(5), 1595-1601. DOI: $10.1021 / \mathrm{jf072582a.}$ 
[74] Windhab E J, Dressler M, Feigl K, Fischer P \& Megias-Alguacil D. (2005). Emulsion processing from single drop deformation to design of complex processes and products. Chemical Engineering Science. 60(8-9), 2101-2113. DOI: 10.1016/j.ces.2004.12.003.

[75] Winsor P A. (1948). Hydrotropy, solubilization and related emulsification processes. Transactions of the Faraday Society. 44, 376-398. DOI: $10.1039 /$ TF9484400376.

[76] Witthayapanyanon A \& Do L. Nanostructureed microemulsions as alternative solvents to VOCs in cleaning technologies and vegetable oil extraction. Retrieved March 24, 2014, from http://www.epa.gov/ncer/publications/workshop/10_ 26_05/abstracts/do.pdf.

[77] Witthayapanyanon A, Do L, Acosta EJ, Harwell JH \& Sabatini DA. (2005). Advanced microemulsion for solvent replacement. $229^{\text {th }}$ ACS National Meeting. San Diego. CA. United States. IEC-072.

[78] Witthayapanyanon A., Acosta EJ., Harwell JH. \& Sabatini DA. (2006). Formulation of ultralow interfacial tension systems using extended surfactants. Journal of Surfactants and Detergents. 9(4), 331-339. DOI: 10.1007/s11743-006-5011-2.

[79] World Agriculture Supply and Demand Estimates. (2014). United States Department of Agriculture. 527, 1-40.

[80] Zhang H, Taxipalati M, Que F \& Feng F. (2013). Microstructure characterization of a food-grade Utype microemulsion system by differential scanning calorimetry and electrical conductivity techniques. Food Chemistry. 141(3), 3050-3055. DOI: 10.1016/j.foodchem.2013.05.141. 